\title{
The Diagnosis of the Bone Age and Prediction of Adult Height by the Ebrí Methods Bernardo Ebri Torné
}

Servicio de Pediatría del Hospital Universitario Miguel Servet de Zaragoz, Spain

Bone maturation is the best overall indicator of biological development we have in the human species. Bone age expresses this maturation process, requiring simple radiological studies for determining, with the left hand radiograph in the opinion of most authors, the preferred anatomical region [1].

The evaluation of the individual's growth and determining periods of intense growth occurring during ripening, provide important clinical information for interdisciplinary diagnosis, especially for pediatric endocrinologist, in order to control a child's normal growth. It is of interest to calculate bone age not only for the pediatrician and endocrinologist, but in sports medicine, in order to avoid negative influences of intensive training on the growth and maturity of young athletes. It is also of interest in Forensic Medicine, when they analyse human remains badly damaged, presumebly belonging to children or young individuals [2-4].

Bone age also provides a basis for predicting namely height and to follow the evolution of the child after a treatment in this regard. It is also of interest to the parents themselves, who want to know the future height of their children [5-6].

To calculate bone age, morphological and numerical methods may be used. We have spent more than 40 years researching in different anatomical regions: Basically we make a historical review of bone age calculation methods and adult height prediction based on regions of the hand and the tarsus, including our own studies [7]. The importance of knowing bone maturation in pediatrics and endocrinology are highlighted in this paper.

Our original method of studying bone age in the carpus and the tarsus in a large cross number of children has been referenced extensively in the literature. A Spanish population of 5225 healthy children was studied by the method IVO carpal and 540 by the method IVO tarsal. 96 fetuses of both sexes in tarsal region were also studied research was published over several years [8-14]. Recently we have studied a longitudinal series of Spanish children to calculate bone age of these children and predict adult height [15-17].

The casuistry of this study comes from the General Survey Anthropometric Aragonés Andrea Prader Somatometric and Radiological Study [18] promoted by the Endocrinology Unit of Miguel Servet Hospital of Zaragoza (Spain).

Let us recall to the readers of his Review that in this longitudinal study we use three ossific indexes: The index obtained for calculating bone age in these areas are: IC (Carpal index), IMF (metacarpal phalanx index), ICMF (carpal metacarpal phalanx index).. This carpo-metacarpophalangeal index (ICMF) is a joint index of the two anatomical regions of the carpal and metacarpal phalanges. These index are the result of the sum of the maximum diameters of the bones of each region studied, measured in mili meters. This methodology can be applied by the pediatrician in their daily. They can be used manually or using a software program.

\section{Publication History:}

Received: April 24, 2017

Accepted: May 01, 2017

Published: May 03, 2017

\section{Keywords:}

Neonatal Seizures, Hemophilia, Metabolism

The measurements of the nuclei are performed with a digital mouse over digital radiography, or a nonius over physical radiography. The program, gives us automatically, the diagnosis of the bone age and the prediction of adult height, when introduced into the measurements of each bone and the size of the child and parents.

All this information can be checked at and downloaded from the website of the College of Physicians of Zaragoza (Spain): www.comz. org.es link-banner: Bone Maturation. The program of the hand is already in free use by pediatricians and radiologists.

Although there is concordance with the main methods of study of the age of the bone: Anglo-Saxon methods of Grulich and Pyle and Tanner, our numerical methods have an advantage over morphological because they have greater accuracy, eliminating asynchrony and the subjectivity of the doctor when he chooses the model radiography in the Atlas of Greulich and Pyle [19]. And with respect to Tanner saves the difficult interpretations that sometimes occur in their last stadiums when giving the scores [20-21].

With our methodology we can dispense the use of American method of Greulich and Pyle, and English Tanner Whitehouse, at least in children of Hispanic origin, since these methods distortive calculate bone age when applied to populations they are not Anglo-Saxons. Our methods present advantages, especially for Latin American population given the provenance of our Hispanic children, but the method itself can be used in other non-Latin American children and allow for research, comparative studies, and creation of new standards of different Areas. Therefore, and given the original universal formula "aseptic" to achieve our indexes of ossification, this formula can be grafted or applied to indigenous populations, so as to have bone ages of children in each country studied and create standards for Hispanic, Anglo, African and Asian children. Comparative studies between them can be made by the researchers in order to create international standards series. The possibilities in this regard are many.

Due to numerous pediatricians and radiologists from different geographic areas, especially in the Latin American area, following our methods, we have been asked to have a new program for calculate automatically, and not only manually [22], the obtaining of the ${ }^{*}$ Corresponding Author: Dr. Bernardo Ebri Torne, Servicio de Pediatría del Hospital Universitario Miguel Servet de Zaragoza, Spain; E-mail: ebri@ebri.es

Citation: Ebri Torne B (2017) The Diagnosis of the Bone Age and Prediction of Adult Height by the Ebrí Methods. Int J Pediatr Neonat Care 2: 123. doi: https:// doi.org/10.15344/2455-2364/2017/123

Copyright: @ 2017 Ebri Torne. This is an open-access article distributed under the terms of the Creative Commons Attribution License, which permits unrestricted use, distribution, and reproduction in any medium, provided the original author and source are credited. 
ossification diagnostic of children of short ages of 0 to 2 and 2 to 4 years, we have decided to create this program. In the child, with specific equations of calculation for these short ages, the diagnosis is more adjusted by avoiding the statistical "weight" of the remaining sample until the age of 20 years. From the personal experience of the method and from suggestions received from other colleagues, we find that in the tarsal region too, our method overestimates bone age in very young children. This fact is due to the influence that the total of the casuistry of the older children also exerts on these short ages. To correct this problem, specific equations for these ages were created in their day for manual resolution [10]. Now, to simplify this question, we have also decided to create another software program for the Tarsian region for these ages, and in addition, the program may also perform the ossific diagnosis by tarsal IVO in ages up to 17 years, using the general equations. This program will be "hung" also soon in the mentioned web of the College of physicians of Zaragoza (Spain).

The casuistry that allows this diagnosis of bone age by the tarsus also comes from a crosssectional Hispanic case, which allows only the diagnosis of bone age but not the prediction of adult height of the longitudinal casuistry Andrea Prader.

Acting jointly on these two anatomical regions: Hand and Tarsus, we can study and improve the ossification diagnosis by acting separately. Using the hand program, not only a correct ossification is achieved but also a predictive estimate of reliable adult height.

\section{Conflict of interest}

No authors have a conflict of interest or any financial tie to disclose.

\section{References}

1. Martí Henneberg C, Roy MP, Passe NP (1975) El análisis de la maduración esquelética en el hombre. Metodología.Med Clin 2: 49.

2. Ebrí Torne B. Maturation (1988) Tarsus and carpal bone (Clinicalradiological study Child) Editorial Heraldo de Aragón. Zaragoza.

3. Peña E, Cardenas E, JL del Olmo (1982) Bone growth and maturation athletes tweens and teens. Galvan and Ramos R (Eds). Antro is Biol. II Colloquium Antro. Physical. J.Comas, México City: Antro Inv Inst 453-466.

4. Eiben OG, Panto E, Cyenis G, Frohlich J (1986) Physique of young female gymnasts. Anthrop Kazl 30: 209-220.

5. Ferrández Longás A. (1975) The bone maturation as a fundamental element forecast human development. Clinical Medicine 64: 97-10.

6. Sobradillo B (1979) Prediction of adult height. monograph on nutrition, growth and development. Research Institute Growth and Development. Faustino Orbegozo Foundation. Bilbao 55-63.

7. Ebrí B, Verde E, Inmaculada M (2016) Bone Maturation and Height Prediction: Historical Review of The Calculation Methods. JIRMERPS 10: 24-33.

8. Ebrí Torne B (1979) Presentation of a new biometric method (IVO) for the assessment of bone age in children. Klink Medizinische 214: 50-56.

9. Ebrí Torné B (1990) Biometric method adaptation al Basic. Acta Pediátrica Scandinavica 79:1242-1243.

10. Ebri Torne B (1993) Biometric method for the ossification evaluation of children since birth up to the ages of two and four, applied to the Tarsus. Acta Paediatrica Scandinavica 82: 872.

11. Ebrí Torne B (1989) Study Spanish population of 5225 and 540 children of both sexes by the set method of Carpo (IVOC) and Tarsus (IVOT). Basic program. Adaptation bone age bone age Ebrí to Greulich-Pyle and Tanner Whitehouse for height prediction. Speech at the Royal Academy of Medicine of Zaragoza. Vol communications conference and the Royal Academy of Medicine of Zaragoza. Course 9-31.

Int J Pediatr Neonat Care

ISSN: 2455-2364
12. Ebri Torne B (1993) New index valuation the ossification of Carpe (IVOC) 5225 Study on Children Spanish. Pediatrics 48: 813-817.

13. Ebrí Torné B (1994) New equations to calculate bone age Carpal in the carpal Ebri method in children from birth to two and four years. Spanish Pediatric Act 52: 79-82.

14. Ebri Torne B (1994) Statistical and descriptive study in Swiss child in the carpal bone age by Tanner and methods Ebrí. Spanish Journal of Hand Surgery 21: 67-75.

15. Ebrí Torné B, Ebrí Verde I (2012) Metacarpophalangeal and carpal numeric indices to calculate bone age and predict adult size. An Pediatr (Barc) 76: 199-213.

16. Ebrí Torné B, Ebrí Verde I (2012) Nuevo índice de valoración ósea Ebrí Carpo metacarpofalángico y de predicción de talla adulta. Pediatr Integral XVI: 822-822

17. Ebrí B, Ebrí I (2013) Biometric Method for the Ossification Evaluation of Children from Birth Up to the ages of Two and Four-Applied to the Metacarpal and Phalanxes in Spanish Longitudinal Series. Cureus 5: 151.

18. Ferrández Longás A, Baguer L (2005) Estudio Longitudinal de niños españoles normales desde el nacimiento hasta la edad adulta. Datos antropométricos, puberales, radiológicose intelectuales. Zaragoza: Fundación Andrea Prader.

19. Greulich WW, Pyle SI (1959) Radiographic Atlas of Skeletal Development of the Hand and Wrist. Second Edition. Stanford University Press.

20. Ebrí Torné B (1996) Indice de valoración Ósea Metacarpofalángico.Estudio Longitudinal de niño Suizo. Estudio comparado con Tanner II Rus.Acta Pediátrica Española 54: 94-102.

21. Ebrí Torné B (1997) Estudio comparativo de las edades óseas TannerRus, Tanner Carpal- Ebrí Carpal, Ebrí Metacarpofalángica, y Greulich y Pyle. Acta Pediátrica Española 55: 369-374. 